\title{
Crafting the Neoliberal State: Workfare, Prisonfare, and Social Insecurity ${ }^{1}$
}

\author{
Loïc Wacquant ${ }^{2}$
}

\begin{abstract}
In Punishing the Poor, I show that the ascent of the penal state in the United States and other advanced societies over the past quarter-century is a response to rising social insecurity, not criminal insecurity; that changes in welfare and justice policies are interlinked, as restrictive "workfare" and expansive "prisonfare" are coupled into a single organizational contraption to discipline the precarious fractions of the postindustrial working class; and that a diligent carceral system is not a deviation from, but a constituent component of, the neoliberal Leviathan. In this article, I draw out the theoretical implications of this diagnosis of the emerging government of social insecurity. I deploy Bourdieu's concept of "bureaucratic field" to revise Piven and Cloward's classic thesis on the regulation of poverty via public assistance, and contrast the model of penalization as technique for the management of urban marginality to Michel Foucault's vision of the "disciplinary society," David Garland's account of the "culture of control," and David Harvey's characterization of neoliberal politics. Against the thin economic conception of neoliberalism as market rule, I propose a thick sociological specification entailing supervisory workfare, a proactive penal state, and the cultural trope of "individual responsibility." This suggests that we must theorize the prison not as a technical implement for law enforcement, but as a core political capacity whose selective and aggressive deployment in the lower regions of social space violates the ideals of democratic citizenship.
\end{abstract}

1 This article is adapted from "A Sketch of the Neoliberal State," the theoretical coda to my book Punishing the Poor: The Neoliberal Government of Social Insecurity (Durham and London: Duke University Press, "Politics, History, and Culture" series, 2009). It is part of a transdisciplinary and transnational symposium, with responses by John Campbell, Bernard Harcourt, Margit Mayer, Jamie Peck, Frances Piven, and Mariana Valverde (published in English in Theoretical Criminology, 14, no. 1, February 2010), as well as critics from the corresponding countries, published in German in Das Argument (Berlin); in French in Civilisations (Brussels); in Spanish in Pensar (Rosario); in Brazilian in Discursos Sediciosos (Rio de Janeiro); in Italian in Aut Aut (Rome); in Portuguese in Cadernos de Ciencias Sociais (Porto); in Norwegian in Materialisten (Oslo); in Danish in Social Kritik (Copenhagen); in Greek in Ikarian Journal of Social and Political Research (Athens); in Ukrainian in Spilne (Kiev); in Russian in Skepsis (Moscow); in Hungarian in Eszmelet (Budapest); in Slovenian in Novi Plamen (Ljubljana); in Romanian in Sociologie Romaneasca (Bucarest); and in Japanese in Gendai Shiso (Tokyo). I am grateful to Mario Candeias and the Rosa Luxemburg Stiftung in Berlin for starting the ball rolling on this project, and to the editors of the journals listed above for their enthusiastic support of this project. This article benefited from reactions to presentations made at the 4th Conference on Putting Pierre Bourdieu to Work, Manchester, United Kingdom, June 23-24, 2008, and to the Sociology Department Colloquium at Yale University, February 26, 2009.

${ }^{2}$ University of California, Berkeley, and Centre de sociologie européenne, Paris, France; e-mail: loic@berkeley.edu. 
KEY WORDS: Bourdieu; citizenship; neoliberalism; prison; poverty; state; welfare; workfare.

\section{INTRODUCTION}

In Punishing the Poor, I show that the return of the prison to the institutional forefront of advanced society over the past quarter-century is a political response, not to rising criminal insecurity, but to the diffuse social insecurity wrought by the fragmentation of wage labor and the shakeup of ethnic hierarchy (Wacquant, 2009a). ${ }^{3}$ The punitive slant of recent shifts in both welfare and justice policies points to a broader reconstruction of the state coupling restrictive "workfare" and expansive "prisonfare" under a philosophy of moral behaviorism. The paternalist penalization of poverty aims to contain the urban disorders spawned by economic deregulation and to discipline the precarious fractions of the postindustrial working class. Diligent and belligerent programs of "law and order" entailing the enlargement and exaltation of the police, the courts, and the penitentiary have also spread across the First world because they enable political elites to reassert the authority of the state and shore up the deficit of legitimacy officials suffer when they abandon the mission of social and economic protection established during the FordistKeynesian era.

Punishing the Poor treats the United States after the acme of the civil rights movement as the historic crucible of punitive containment as technique for the management of marginality and living laboratory of the neoliberal future where the convergent revamping of the social and penal wings of the state can be discerned with particular clarity. Its overarching argument unfolds in four steps. Part 1 maps out the accelerating decline and abiding misery of the U.S. social state, climaxing with the replacement of protective welfare by disciplinary workfare in 1996. Part 2 tracks the modalities of the growth and grandeur of the penal state and finds that the coming of "carceral big government" was driven not by trends in criminality, but by the class and racial backlash against the social advances of the 1960s. Part 3 heeds the communicative dimension of penality as a vehicle for symbolic boundary drawing and explains why penal activism in the United States has been aimed at two "privileged targets," the black subproletariat trapped in the imploding ghetto and the roaming sex offender. Part 4 follows recent declinations of the new politics of social insecurity in Western Europe to offer a critique of the "scholarly myths" of the reigning law-and-order reason, prescriptions for

3 The fragmentation of wage labor and its reverberations at the lower end of the class structure are documented by Freeman (2007) for the United States and by Gallie (2007) for the European Union. Ethnic hierarchy is anchored by the ethnoracial division between whites and blacks in the United States (other categories finding their place in this dichotomous ordering through a process of triangulation) and by the ethnonational duality between citizens and postcolonial migrants in Western Europe. Massey (2007) and Schierup et al. (2006) display similarities and differences in ethnic stratification on the two sides of the Atlantic, including the massive overrepresentation of dishonored populations behind bars. 
escaping the punitive policy snare, and a characterization of the distinctive shape and missions of the neoliberal state.

Three analytic breaks proved indispensible to diagnose the invention of a new government of social insecurity wedding supervisory "workfare" and castigatory "prisonfare," and to account for the punitive policy turn taken by the United States and other advanced societies following its lead onto the path of economic deregulation and welfare retrenchment in the closing decades of the twentieth century. The first consists in escaping the crime-and-punishment poke, which continues to straightjacket scholarly and policy debates on incarceration, even as the divorce of this familiar couple grows ever more barefaced. ${ }^{4}$ The second requires relinking social welfare and penal policies, inasmuch these two strands of government action toward the poor have come to be informed by the same behaviorist philosophy relying on deterrence, surveillance, stigma, and graduated sanctions to modify conduct. Welfare revamped as workfare and the prison stripped of its rehabilitative pretension now form a single organizational mesh flung at the same clientele mired in the fissures and ditches of the dualizing metropolis. They work jointly to invisibilize problem populations - by forcing them off the public aid rolls, on the one side, and holding them under lock, on the other-and eventually push them into the peripheral sectors of the booming secondary labor market. The third rupture involves overcoming the conventional opposition between materialist and symbolic approaches, descended from the emblematic figures of Karl Marx and Émile Durkheim, so as to heed and hold together the instrumental and the expressive functions of the penal apparatus. ${ }^{5}$ Weaving together concerns for control and communication, the management of dispossessed categories and the affirmation of salient social borders, makes it possible to go beyond an analysis couched in the language of prohibition to trace how the rolling out of the prison and its institutional tentacles (probation, parole, criminal databases, swirling discourses about crime, and a virulent culture of public denigration of offenders) has reshaped the sociosymbolic landscape and remade the state itself.

A single concept sufficed to effect those three breaks simultaneously: the notion of bureaucratic field developed by Pierre Bourdieu (1994) in his lecture course at the Collège de France in the early 1990s to rethink the state as the agency that monopolizes the legitimate use not only of material violence (as in

${ }^{4}$ A simple statistic suffices to demonstrate this disconnect and reveals the futility of trying to explain rising incarceration by escalating crime: the United States held 21 prisoners for every 1,000 "index crimes" in 1975 compared to 113 convicts per 1,000 crimes in 2000, for an increase of $438 \%$; for "violent crimes," the jump is from 231 to 922 convicts per 1,000 offenses, an increase of $299 \%$. This means that the country became four to five times more punitive in a quarter-century holding crime constant (a lagged index turns up the same trend). See Wacquant (2009a:125-133) for further elaboration and Blumstein and Wallman (2000) and Western (2006:ch. 2) for different approaches leading to the same conclusion.

5 Garland (1989) dissects the materialist (Marxist) and symbolic (Durkheimian) lineages in the study of punishment and proposes that they, along with Foucault, Weber, and Elias, offer "resources to be drawn upon selectively rather than inviolable world-views which can only be swallowed whole", (1989:278). 
Max Weber's well-known capsule), but also of symbolic violence, and shapes social space and strategies by setting the conversion rate between the various species of capital. In this article, I extend Bourdieu's formulation to draw out the theoretical underpinnings and implications of the model of the neoliberal government of social insecurity at century's dawn put forth in Punishing the Poor. In the first section, I revise Piven and Cloward's classic thesis on the regulation of poverty via public assistance and contrast penalization as a technique for the management of marginality in the dual metropolis with Michel Foucault's vision of the place of the prison in the "disciplinary society," David Garland's account of the crystallization of the "culture of control" in late modernity, and David Harvey's characterization of neoliberal politics and its proliferation on the world stage. In the second section, I build on these contrasts to elaborate a thick sociological specification of neoliberalism that breaks with the thin economic conception of neoliberalism as market rule that effectively echoes its ideology. I argue that a proactive penal system is not a deviation from, but a constituent component of, the neoliberal Leviathan, along with variants of supervisory workfare and the cultural trope of "individual responsibility." This suggests that we need to theorize the prison not as a technical implement for law enforcement, but as a core organ of the state whose selective and aggressive deployment in the lower regions of social space is constitutively injurious to the ideals of democratic citizenship.

\section{WHEN WORKFARE JOINS PRISONFARE: THEORETICAL IMPLICATIONS}

In The Weight of the World and related essays, Pierre Bourdieu proposes that we construe the state not as a monolithic and coordinated ensemble, but as a splintered space of forces vying over the definition and distribution of public goods, which he calls the "bureaucratic field." 6 The constitution of this space is the end result of a long-term process of concentration of the various species of capital operative in a given social formation, and especially of "juridical capital as the objectified and codified form of symbolic capital," which enables the state to monopolize the official definition of identities, the promulgation of standards of conduct, and the administration of justice (Bourdieu, 1994:4, 9). In the contemporary period, the bureaucratic field is traversed by two internecine struggles. The first pits the "higher state nobility" of policymakers intent on promoting market-oriented reforms and the "lower state nobility" of executants attached to the traditional missions of

6 The concept is sketched analytically in Bourdieu (1994), illustrated in Bourdieu (1999), and deployed to probe the political production of the economy of single homes in France in Bourdieu (2005). Several issues of the journal Actes de la recherche en sciences sociales offer further cross-national empirical illustrations, including those on "The History of the State" (nos. 116 and 117, March 1997), "The Genesis of the State" (no. 118, June 1997), the transition "From Social State to Penal State" (no. 124, September 1998), and "Pacify and Punish" (nos. 173 and 174, June and September 2008). 
government. The second opposes what Bourdieu, riding off Hobbes's classic portrayal of the ruler, calls the "Left hand" and the "Right hand" of the state. The Left hand, the feminine side of Leviathan, is materialized by the "spendthrift" ministries in charge of "social functions"-public education, health, housing, welfare, and labor law-which offer protection and succor to the social categories shorn of economic and cultural capital. The Right hand, the masculine side, is charged with enforcing the new economic discipline via budget cuts, fiscal incentives, and economic deregulation.

By inviting us to grasp in a single conceptual framework the various sectors of the state that administer the life conditions and chances of the working class, and to view these sectors as enmeshed in relations of antagonistic cooperation as they vie for preeminence inside the bureaucratic field, this conception has helped us map the ongoing shift from the social to the penal treatment of urban marginality. In this regard, Punishing the Poor fills in a gap in Bourdieu's model by inserting the police, the courts, and the prison as core constituents of the "Right hand" of the state, alongside the ministries of the economy and the budget. It suggests that we need to bring penal policies from the periphery to the center of our analysis of the redesign and deployment of government programs aimed at coping with the entrenched poverty and deepening disparities spawned in the polarizing city by the discarding of the Fordist-Keynesian social compact (Musterd et al., 2006; Wilson, 1996; Wacquant, 2008a). The new government of social insecurity put in place in the United States and offered as model to other advanced countries entails both a shift from the social to the penal wing of the state (detectable in the reallocation of public budgets, personnel, and discursive precedence) and the colonization of the welfare sector by the panoptic and punitive logic characteristic of the postrehabilitation penal bureaucracy. The slanting of state activity from the social to the penal arm and the incipient penalization of welfare, in turn, partake of the remasculinization of the state, in reaction to the wideranging changes provoked in the political field by the women's movement and by the institutionalization of social rights antinomic to commodification. The new priority given to duties over rights, sanction over support, the stern rhetoric of the "obligations of citizenship," and the martial reaffirmation of the capacity of the state to lock the trouble-making poor (welfare recipients and criminals) "in a subordinate relation of dependence and obedience" toward state managers portrayed as virile protectors of the society against its wayward members (Young, 2005:16): all these policy planks pronounce and promote the transition from the kindly "nanny state" of the FordistKeynesian era to the strict "daddy state" of neoliberalism.

In their classic study Regulating the Poor, Frances Fox Piven and Richard Cloward forged a germinal model of the management of poverty in industrial capitalism. According to this model, the state expands or contracts its relief programs cyclically to respond to the ups and downs of the economy, the corresponding slackening and tightening of the labor market, and the bouts of social disruption that increased unemployment and destitution trigger 
periodically among the lower class. Phases of welfare expansion serve to "mute civil disorders" that threaten established hierarchies, while phases of restriction aim to "enforce works norms" by pushing recipients back into the labor market (Piven and Cloward, 1993:xvi and passim). Punishing the Poor contends that, while this model worked well for the age of Fordist industrialism and accounts for the two major welfare explosions witnessed in the United States during the Great Depression and the affluent but turbulent 1960s, it has been rendered obsolete by the neoliberal remaking of the state over the past quarter-century. In the age of fragmented labor, hypermobile capital, and sharpening social inequalities and anxieties, the "central role of relief in the regulation of marginal labor and in the maintenance of social order" (Piven and Cloward, 1993:xviii) is displaced and duly supplemented by the vigorous deployment of the police, the courts, and the prison in the nether regions of social space. To the single oversight of the poor by the Left hand of the state succeeds the double regulation of poverty by the joint action of punitive welfareturned-workfare and an aggressive penal bureaucracy. The cyclical alternation of contraction and expansion of public aid is replaced by the continual contraction of welfare and the runaway expansion of prisonfare. ${ }^{7}$

This organizational coupling of the Left hand and Right hand of the state under the aegis of the same disciplinary philosophy of behaviorism and moralism can be understood, first, by recalling the shared historical origins of poor relief and penal confinement in the chaotic passage from feudalism to capitalism. Both policies were devised in the long sixteenth century to "absorb and regulate the masses of discontented people uprooted" by this epochal transition (Piven and Cloward, 1993:21). ${ }^{8}$ Similarly, both policies were overhauled in the last two decades of the twentieth century in response to the socioeconomic dislocations provoked by neoliberalism: in the 1980s alone, in addition to reducing public assistance, California passed nearly 1,000 laws expanding the use of prison sentences; at the federal level, the 1996 reform that "ended welfare as we know it" was complemented by the sweeping Violent Crime Control and Law Enforcement Act of 1993 and bolstered by the No Frills Prison Act of 1995.

The institutional pairing of public aid and incarceration as tools for managing the unruly poor can also be understood by paying attention to the structural, functional, and cultural similarities between workfare and prisonfare as "people-processing institutions" targeted on kindred problem

7 By analogy with "welfare," I designate by "prisonfare" the policy stream through which the state gives a penal response to festering urban ills and sociomoral disorders, as well as the imagery, discourses, and bodies of lay and expert knowledge that accrete around the rolling out of the police, the courts, jails, and prisons, and their extensions (probation, parole, computerized databanks of criminal files, and the schemes of remote profiling and surveillance they enable). Penalization joins socialization and medicalization as the three alternative strategies whereby the state can opt to treat undesirable conditions and conduct (Wacquant, 2009a:16-17).

8 Piven and Cloward (1993:20, note 23) acknowledge penal expansion and activism in the sixteenth century in passing in the rich historical recapitulation of the trajectory of poor relief in early modern Europe in which they ground their investigation of the functions of welfare in the contemporary United States. 
populations (Hasenfeld, 1972). It has been facilitated by the transformation of welfare in a punitive direction and the activation of the penal system to handle more of the traditional clientele of assistance to the destitute - the incipient "penalization" of welfare matching the degraded "welfarization" of the prison. Their concurrent reform over the past 30 years has helped cement their organizational convergence, even as they have obeyed inverse principles. The gradual erosion of public aid and its revamping into workfare in 1996 has entailed restricting entry into the system, shortening "stays" on the rolls, and speeding up exit, resulting in a spectacular reduction of the stock of beneficiaries (it plummeted from nearly 5 million households in 1992 to under 2 million a decade later). Trends in penal policy have followed the exact opposite tack: admission into jail and prison has been greatly facilitated, sojourns behind bars lengthened, and releases curtailed, which has yielded a spectacular ballooning of the population under lock (it jumped by over 1 million in the 1990s). The operant purpose of welfare has shifted from passive "people processing" to active "people changing" after 1988 and especially after the abolition of AFDC in 1996, while the prison has traveled in the other direction, from aiming to reform inmates (under the philosophy of rehabilitation, hegemonic from the 1920s to the mid-1970s) to merely warehousing them (as the function of punishment was downgraded to retribution and neutralization).

The shared historical roots, organizational isomorphism, and operational convergence of the assistential and penitential poles of the bureaucratic field in the United States are further fortified by the fact that the social profiles of their beneficiaries are virtually identical. AFDC recipients and jail inmates both live near or below $50 \%$ of the federal poverty line (for one-half and twothirds of them, respectively); both are disproportionately black and Hispanic ( $37 \%$ and $18 \%$ vs. $41 \%$ and $19 \%$ ); the majority did not finish high school and are saddled with serious physical and mental disabilities interfering with their participation in the workforce $(44 \%$ of AFDC mothers as against $37 \%$ of jail inmates). And they are closely bound to one another by extensive kin, marital and social ties, reside overwhelmingly in the same impoverished households and barren neighborhoods, and face the same bleak life horizon at the bottom of the class and ethnic structure.

Punishing the Poor avers not only that the United States has shifted from the single (welfare) to the double (social-cum-penal) regulation of the poor, but also that that "the stunted development of American social policy" skillfully dissected by Piven and Cloward (1993:409) stands in close causal and functional relation to America's uniquely overgrown and hyperactive penal policy. The misery of American welfare and the grandeur of American prisonfare at century's turn are the two sides of the same political coin. The generosity of the latter is in direct proportion to the stinginess of the former, and it expands to the degree that both are driven by moral behaviorism. The same structural features of the U.S. state - its bureaucratic fragmentation and ethnoracial skew, the institutional bifurcation between universalist "social insurance" and categorical "welfare," and the market-buttressing cast of 
assistance programs - that facilitated the organized atrophy of welfare in reaction to the racial crisis of the 1960s and the economic turmoil of the 1970s have also fostered the uncontrolled hypertrophy of punishment aimed at the same precarious population. Moreover, the "tortured impact of slavery and institutionalized racism on the construction of the American polity" has been felt, not only on the "underdevelopment" of public aid and the "decentralized and fragmented government and party system" that distributes it to a select segment of the dispossessed (Piven and Cloward, 1993:424-425), but also on the overdevelopment and stupendous severity of its penal wing. Ethnoracial division and the (re)activation of the stigma of blackness as dangerousness are key to explaining the initial atrophy and accelerating decay of the U.S. social state in the post civil rights epoch, on the one hand, and the astonishing ease and celerity with which the penal state arose on its ruins, on the other. ${ }^{9}$

Reversing the historical bifurcation of the labor and crime questions achieved in the late nineteenth century, punitive containment as a government technique for managing deepening urban marginality has effectively rejoined social and penal policy at the close of the twentieth century. It taps the diffuse social anxiety coursing through the middle and lower regions of social space in reaction to the splintering of wage work and the resurgence of inequality, and converts it into popular animus toward welfare recipients and street criminals cast as twin detached and defamed categories that sap the social order by their dissolute morality and dissipated behavior and must therefore be placed under severe tutelage. The new government of poverty invented by the United States to enforce the normalization of social insecurity thus gives a whole new meaning to the notion of "poor relief": punitive containment offers relief not to the poor but from the poor by forcibly "disappearing" the most disruptive of them, from the shrinking welfare rolls on the one hand and into the swelling dungeons of the carceral castle on the other.

Michel Foucault (1977) has put forth the single most influential analysis of the rise and role of the prison in capitalist modernity, and it is useful to set my thesis against the rich tapestry of analyses he has stretched and stimulated. I concur with the author of Discipline and Punish that penality is a protean force that is eminently fertile and must be given pride of place in the study of contemporary power. ${ }^{10}$ While its originary medium resides in the application of legal coercion to enforce the core strictures of the sociomoral order,

9 The catalytic role of ethnoracial division in the remaking of the state after the junking of the Fordist-Keynesian social compact and the collapse of the dark ghetto is analyzed in full in my book Deadly Symbiosis: Race and the Rise of the Penal State (Wacquant, 2010). The depth and rigidity of racial partition is a major factor behind the abyssal gap between the incarceration rates of the United States and European Union, just as it explains their divergent rates of poverty (Alesina and Glaeser, 2004).

10 Foucault's writings on incarceration are dispersed and multifaceted, comprising some 60 texts written over 15 years cutting across disciplinary domains and serving manifold purposes from the analytic to the political, and it is not possible to consider them in their richness and complexity here (these are captured by Boullant [2003]). Instead, I focus on the canonical tome, Surveiller et punir. Naissance de la prison (Foucault, 1975). I give my own translation with page references to the original French edition, followed by the pagination in the U.S. edition. 
punishment must be viewed not through the narrow and technical prism of repression, but by recourse to the notion of production. The assertive rolling out of the penal state has indeed engendered new categories and discourses, novel administrative bodies and government policies, fresh social types, and associated forms of knowledge across the criminal and social welfare domains (Wacquant, 2008b). But, from here, my argument diverges sharply from Foucault's view of the emergence and functioning of the punitive society in at least four ways.

To start with, Foucault erred in spotting the retreat of the penitentiary. Disciplines may have diversified and metastasized to thrust sinewy webs of control across the society, but the prison has not for that receded from the historical stage and "lost its raison d'être" (Foucault, 1977:304-305/297-298). On the contrary, penal confinement has made a stunning comeback and reaffirmed itself among the central missions of Leviathan just as Foucault and his followers were forecasting its demise. After the founding burst of the $1600 \mathrm{~s}$ and the consolidation of the 1800s, the turn of the present century ranks as the third "age of confinement" that penologist Thomas Mathiesen (1990) forewarned about in 1990. Next, whatever their uses in the eighteenth century, disciplinary technologies have not been deployed inside the overgrown and voracious carceral system of our fin de siècle. Hierarchical classification, elaborate time schedules, nonidleness, close-up examination and the regimentation of the body: these techniques of penal "normalization" have been rendered wholly impracticable by the demographic chaos spawned by overpopulation, bureaucratic rigidity, resource depletion, and the studious indifference if not hostility of penal authorities toward rehabilitation. ${ }^{11}$ In lieu of the dressage ("training" or "taming") intended to fashion "docile and productive bodies" postulated by Foucault, the contemporary prison is geared toward brute neutralization, rote retribution, and simple warehousing - by default if not by design. If there are "engineers of consciousness" and "orthopedists of individuality" at work in the mesh of disciplinary powers today (Foucault, 1977: 301/294), they surely are not employed by departments of corrections.

In the third place, "devices for normalization" anchored in the carceral institution have not spread throughout the society, in the manner of capillaries irrigating the entire body social. Rather, the widening of the penal dragnet under neoliberalism has been remarkably discriminating: in spite of conspicuous bursts of corporate crime (epitomized by the Savings and Loans scandal of the late 1980s and the folding of Enron a decade later), it has affected essentially the denizens of the lower regions of social and physical space. Indeed, the fact that the social and ethnoracial selectivity of the prison has been maintained, nay reinforced, as it vastly enlarged its intake demonstrates

11 This is particularly glaring in the country's second largest carceral system (after the Federal Bureau of Prisons), the California Department of Corrections, in which grotesque overcrowding (the state packs 170,000 convicts in 33 prisons designed to hold 85,000) and systemic bureaucratic dysfunction combine to make a mockery of any pretense at "rehabilitation" (Petersilia, 2008). 
that penalization is not an all-encompassing master logic that blindly traverses the social order to bend and bind its various constituents. On the contrary: it is a skewed technique proceeding along sharp gradients of class, ethnicity, and place, and it operates to divide populations and to differentiate categories according to established conceptions of moral worth. At the dawn of the twenty-first century, America's urban (sub)proletariat lives in a "punitive society," but its middle and upper classes certainly do not. Similarly, efforts to import and adapt U.S.-style slogans and methods of law enforcement - such as zero tolerance policing, mandatory minimum sentencing, or boot camps for juveniles - in Europe have been trained on lower-class and immigrant offenders relegated in the defamed neighborhoods at the center of the panic over "ghettoization" that has swept across the continent over the past decade (Wacquant, 2009b).

Lastly, the crystallization of law-and-order pornography, that is, the accelerating inflection and inflation of penal activity conceived, represented, and implemented for the primary purpose of being displayed in ritualized form by the authorities - the paradigm for which is the half-aborted reintroduction of chain gangs in striped uniforms - suggests that news of the death of the "spectacle of the scaffold" has been greatly exaggerated. The "redistribution" of "the whole economy of punishment" (Foucault, 1977:13/7) in the post-Fordist period has entailed not its disappearance from public view as proposed by Foucault, but its institutional relocation, symbolic elaboration, and social proliferation beyond anything anyone envisioned when Discipline and Punish was published. In the past quarter-century, a whole galaxy of novel cultural and social forms, indeed a veritable industry trading on representations of offenders and law enforcement, has sprung forth and spread. The theatricalization of penality has migrated from the state to the commercial media and the political field in toto, and it has extended from the final ceremony of sanction to encompass the full penal chain, with a privileged place accorded to police operations in low-income districts and courtroom confrontations around celebrity defendants. The Place de grève, where the regicide Damiens was famously quartered, has thus been supplanted not by the Panopticon but by Court TV and the profusion of crime-and-punishment "reality shows" that have inundated television (Cops, 911, America's Most Wanted, American Detective, Bounty Hunters, Inside Cell Block $F$, etc.), not to mention the use of criminal justice as fodder for the daily news and dramatic series (Law and Order, CSI, Prison Break, etc.). So much to say that the prison did not "replace" the "social game of the signs of punishment and the garrulous feast that put them in motion" (Foucault, 1977:134/131). Rather, it now serves as its institutional canopy. Everywhere the law-and-order guignol has become a core civic theater onto whose stage elected officials prance to dramatize moral norms and display their professed capacity for decisive action, thereby reaffirming the political relevance of Leviathan at the very moment when they organize its powerlessness with respect to the market.

This brings us to the question of the political proceeds of penalization, a theme central to David Garland's book The Culture of Control, the most 
sweeping and stimulative account of the nexus of crime and social order put forth since Foucault. ${ }^{12}$ According to Garland, "the distinctive social, economic, and cultural arrangements of late modernity" have fashioned a "new collective experience of crime and insecurity," to which the authorities have given a reactionary interpretation and a bifurcated response combining practical adaptation via "preventative partnerships" and hysterical denial through "punitive segregation" (Garland, 2001:139-147 and passim). The ensuing reconfiguration of crime control bespeaks the inability of rulers to regiment individuals and normalize contemporary society, and its very disjointedness has made glaring to all the "limits of the sovereign state." For Garland, the "culture of control" coalescing around the "new criminological predicament" pairing high crime rates with the acknowledged limitations of criminal justice both marks and masks a political failing. On the contrary, Punishing the Poor asserts that punitive containment has proved to be a remarkably successful political strategy: far from "eroding one of the foundational myths of modern society," which holds that "the sovereign state is capable of delivering law and order" (Garland, 2001:109), it has revitalized it. This is true not only in the United States, where the leaders of both parties have reached complete consensus over the benefits of punitive penal policies targeted at the inner city (Chih Lin, 1998), but also in Europe: Blair in the United Kingdom, Berlusconi in Italy, and Chirac and Sarkozy in France have all parlayed their martial images of stern "crime fighters" intent to clean up the streets into victories at the polls. ${ }^{13}$

By elevating criminal safety (sécurité, Sicherheit, sicurezza, etc.) to the frontline of government priorities, state officials have condensed the diffuse class anxiety and simmering ethnic resentment generated by the unraveling of the Fordist-Keynesian compact and channeled them toward the (dark-skinned) street criminal, designated as guilty of sowing social and moral disorder in the city, alongside the profligate welfare recipient. Rolling out the penal state and coupling it with workfare has given the high state nobility an effective tool to both foster labor deregulation and contain the disorders that economic deregulation provokes in the lower rungs of the sociospatial hierarchy. Most importantly, it has allowed politicians to make up for the deficit of legitimacy that besets them whenever they curtail the economic support and social protections traditionally granted by Leviathan. Contra Garland, then, I find that the penalization of urban poverty has served well as a vehicle for the

${ }^{12}$ Since its publication in 2001, Garland has engaged in extensive debates on the "culture of control" (e.g., Garland, 2004), revising and qualifying his thesis on multiple fronts. For reasons of space and consistency, I concentrate on the model presented in the book and spotlight those elements that contrast Garland's portrayal of the crime-and-punishment duet in "late modernity" with the analysis of neoliberal penalization offered in Punishing the Poor (I do not discuss, for instance, Garland's analysis of "shifts in private behaviors" spurred by cultural adaptations to the "high-crime society" by households, businesses, victims, etc., as these are irrelevant to the characterization of the penal state proper).

${ }^{13}$ See Shea (2009) for a comparison of the electoral success of law-and-order campaigns in France and Italy. 
ritual reassertion of the sovereignty of the state in the narrow, theatricalized domain of law enforcement that it has prioritized for that very purpose, just when the same state is conceding its incapacity to control flows of capital, bodies, and signs across its borders. This divergence of diagnosis, in turn, points to three major differences between our respective dissections of the punitive drift in First-world countries.

First, the fast and furious bend toward penalization observed at the fin de siècle is not a response to criminal insecurity but to social insecurity. To be more precise, the currents of social anxiety that roil advanced society are rooted in objective social insecurity among the postindustrial working class, whose material conditions have deteriorated with the diffusion of unstable and underpaid wage labor shorn of the usual social "benefits," and subjective insecurity among the middle classes, whose prospects for smooth reproduction or upward mobility have dimmed as competition for valued social positions has intensified and the state has reduced its provision of public goods. Garland's notion that "high rates of crime have become a normal social fact - a routine part of modern consciousness, an everyday risk to be assessed and managed" by "the population at large," and especially by the middle class, is belied by victimization studies. Official statistics show that law breaking in the United States declined or stagnated for 20 years after the mid-1970s before falling precipitously in the 1990s, while exposure to violent offenses varied widely by location in social and physical space (Wacquant, 2009b:144-147). Relatedly, European countries sport crime rates similar to or higher than that of the United States (except for the two specific categories of assault and homicide, which compose but a tiny fraction of all offenses), and yet they have responded quite differently to criminal activity, with rates of incarceration one-fifth to one-tenth the American rate even as they have risen.

This takes us to the second difference: for Garland the reaction of the state to the predicament of high crime and low justice efficiency has been disjointed and even schizoid, whereas I have stressed its overall coherence. However, this coherence becomes visible only when the analytic compass is fully extended beyond the crime-punishment box and across policy realms to link penal trends to the socioeconomic restructuring of the urban order, on the one side, and to join workfare to prisonfare, on the other. What Garland characterizes as "the structured ambivalence of the state's response" is not so much ambivalence as a predictable organizational division in the labor of management of the disruptive poor. Bourdieu's theory of the state is helpful here in enabling us to discern that the "adaptive strategies" recognizing the state's limited capacity to stem crime by stressing prevention and devolution are pursued in the penal sector of the bureaucratic field, while what Garland calls the "nonadaptive strategies" of "denial and acting out" to reassert that very capacity operate in the political field, especially in its relation to the journalistic field. ${ }^{14}$

14 The analytic and historical differentiation of the political from the bureaucratic field, and their respective locations inside the field of power, is discussed in Wacquant (2005:esp 6-7, 14-17, 142-146). 
Third, like other leading analysts of contemporary punishment such as Jock Young (1999), Franklin Zimring (Zimring et al., 2001), and Michael Tonry (2004), Garland sees the punitive turn as the reactionary spawn of right-wing politicians. But Punishing the Poor finds, first, that the penalization of poverty is not a simple return to a past state of affairs but a genuine institutional innovation and, second, that it is by no means the exclusive creature of neoconservative politics. If politicians of the Right invented the formula, it was employed and refined by their centrist and even "progressive" rivals. Indeed, the president who oversaw by far the biggest increase in incarceration in U.S. history is not Ronald Reagan but William Jefferson Clinton. Across the Atlantic, it is the Left of Blair in the United Kingdom, Schröder in Germany, Jospin in France, d'Alema in Italy, and Gonzalez in Spain who negotiated the shift to proactive penalization, not their conservative predecessors. This is because the root cause of the punitive turn is not late modernity but neoliberalism, a project that can be indifferently embraced by politicians of the Right or the Left.

The jumble of trends that Garland gathers under the umbrella term of late modernity - the "modernizing dynamic of capitalist production and market exchange," shifts in household composition and kinship ties, changes in urban ecology and demography, the disenchanting impact of the electronic media, the "democratization of social life and culture" - are not only exceedingly vague and loosely correlated; they are either not peculiar to the closing decades of the twentieth century, specific to the United States, or show up in their most pronounced form in the social-democratic countries of Northern Europe that have not been submerged by the international wave of penalization. ${ }^{15}$ Moreover, the onset of late modernity has been gradual and evolutionary, whereas the recent permutations of penality have been abrupt and revolutionary.

Punishing the Poor contends that it is not the generic "risks and anxieties" of "the open, porous, mobile society of strangers that is late modernity" (Garland, 2001:165) that have fostered retaliation against lower-class categories perceived as undeserving and deviant types seen as irrecuperable, but the specific social insecurity generated by the fragmentation of wage labor, the hardening of class divisions, and the erosion of the established ethnoracial hierarchy guaranteeing an effective monopoly over collective honor to whites in the United States and to nationals in the European Union. The sudden expansion and consensual exaltation of the penal state after the mid-1970s is not a culturally reactionary reading of "late modernity," but a ruling-class

15 Read the extended analysis of the sociopolitical foundations of the "penal exceptionalism" of Finland, Sweden, and Norway by John Pratt (2008a,b), in which the cultural commitment to social equality and welfare state security play a pivotal role, as they do in the sturdy resistance of Scandinavia to neoliberal nostrums. Another notable anomaly for the "culture of control" thesis is Canada, which is as "late modern" as the United States and yet has kept its incarceration low and stable over the past three decades (it even decreased from 123 to 108 inmates per 100,000 residents between 1991 and 2004, while the U.S. rate zoomed from 360 to 710 inmates per 100,000). 
response aiming to redefine the perimeter and missions of Leviathan so as to establish a new economic regime based on capital hypermobility and labor flexibility and to curb the social turmoil generated at the foot of the urban order by the public policies of market deregulation and social welfare retrenchment that are core building blocks of neoliberalism.

\section{TOWARD A SOCIOLOGICAL SPECIFICATION OF NEOLIBERALISM}

The invention of the double regulation of the insecure fractions of the postindustrial proletariat via the wedding of social and penal policy at the bottom of the polarized class structure is a major structural innovation that takes us beyond the model of the welfare-poverty nexus elaborated by Piven and Cloward just as the Fordist-Keynesian regime was coming unglued. The birth of this institutional contraption is also not captured by Michel Foucault's vision of the "disciplinary society" or by David Garland's notion of the "culture of control," neither of which can account for the unforeseen timing, steep socioethnic selectivity, and peculiar organizational path of the abrupt turnaround in penal trends in the closing decades of the twentieth century. For the punitive containment of urban marginality through the simultaneous rolling back of the social safety net and the rolling out of the policeand-prison dragnet and their knitting together into a carceral-assistential lattice is not the spawn of some broad societal trend - whether it be the ascent of "biopower" or the advent of "late modernity"- but, at bottom, an exercise in state crafting. It partakes of the correlative revamping of the perimeter, missions, and capacities of public authority on the economic, social welfare, and penal fronts. This revamping has been uniquely swift, broad, and deep in the United States, but it is in progress - or in question - in all advanced societies submitted to the relentless pressure to conform to the U.S. pattern.

Consider trends in France: in recent years the country has eased strictures on part-time employment as well as limitations on night-time and weekend work. Its governments of both Left and Right have actively supported the development of short-term contracts, temporary jobs, and underpaid traineeships, and expanded the latitude of employers in hiring, firing, and the use of overtime. The result is that the number of precarious wage earners has risen from 1.7 million in 1992 to 2.8 million in 2007 - or from $8.6 \%$ to $12.4 \%$ of the employed workforce (Maurin and Savidan, 2008). In June 2009, France instituted the RSA (Revenu de solidarité active), set to gradually replace the RMI (Revenu minimum d'insertion, the guaranteed minimum income grant provided to some 1.3 million), a program designed to push public aid recipients into the low-wage labor market via state subsidies to poor workers premised on the obligation to accept employment (Grandquillot, 2009). Simultaneously, the oversight of unemployment benefits is being farmed out to private firms, which can terminate beneficiaries who reject two job offers and receive a financial bonus for each recipient they place in a job. On the penal 
front, accelerating the punitive turn taken by the Socialist government of Jospin in 1998-2002, the successive administrations of Chirac and Sarkozy have adopted sweeping measures of penal expansion (Bonelli, 2008): intensified policing centered on low-income districts, youth night curfews, enlarged recourse to incarceration for street crimes (in sharp contrast to the depenalization of corporate crime), plea bargaining and accelerated judicial processing for low-level delinquents, mandatory minimum sentences for youth recidivists, annual targets for the expulsion of undocumented migrants, and the indefinite civil commitment of certain categories of sex offenders after they have served their sentence. The country's budget for corrections jumped from 1.4 billion euros for 22,000 guards confining 48,000 inmates in 2001 to 2 billion euros for 24,000 guards and 64,000 inmates in 2009.

Tracking the roots and modalities of America's stupendous drive to hyperincarceration opens a unique route into the sanctum of the neoliberal Leviathan. It leads us to articulate two major theoretical claims. The first is that the penal apparatus is a core organ of the state, expressive of its sovereignty and instrumental in imposing categories, upholding material and symbolic divisions, and molding relations and behaviors through the selective penetration of social and physical space. The police, the courts, and the prison are not mere technical appendages for the enforcement of lawful order (as criminology would have it), but vehicles for the political production of reality and for the oversight of deprived and defamed social categories and their reserved territories (Wacquant, 2008b). Students of early modern state formation, from Norbert Elias to Charles Tilly to Gianfranco Poggi, fully recognized that the monopolization of force, and thus the construction of a bureaucratic machinery for policing, judging, and punishing miscreants capable of minimally pacifying society, was central to the building of Leviathan. It is high time that students of the neoliberal era notice that the remaking of the state after the breakup of the Keynesian social compact has entailed not only renewed activity aimed at fostering international competitiveness, technological innovation, and labor flexibility (Jessop, 1994; Levy 2006; Streeck and Thelen, 2005) but also, and most distinctively, the forceful reassertion of its penal mission henceforth set in a pornographic and managerialist key.

Indeed, the second thesis advanced by Punishing the Poor is that the ongoing capitalist "revolution from above," commonly called neoliberalism, entails the enlargement and exaltation of the penal sector of the bureaucratic field, so that the state may check the social reverberations caused by the diffusion of social insecurity in the lower rungs of the class and ethnic hierarchy as well as assuage popular discontent over the dereliction of its traditional economic and social duties. Neoliberalism readily resolves what for Garland's "culture of control" remains an enigmatic paradox of late modernity, namely, the fact that "control is now being re-emphasized in every area of social lifewith the singular and startling exception of the economy, from whose deregulated domain most of today's major risks routinely emerge" (Garland, 2001:165, emphasis supplied). The neoliberal remaking of the state also explains the 
steep class, ethnoracial, and spatial bias stamping the simultaneous retraction of its social bosom and expansion of its penal fist: the populations most directly and adversely impacted by the convergent revamping of the labor market and public aid turn out also to be the privileged "beneficiaries" of the penal largesse of the authorities. This is true in the United States where the carceral boom has corralled (sub)proletarian blacks trapped in the bare hyperghetto. It is also the case in Western Europe, where the primary clientele of the expanding prison is composed of precarious workers and the unemployed, postcolonial migrants, and lower-class addicts and derelicts (Wacquant, 2009b:87-102).

Finally, neoliberalism correlates closely with the international diffusion of punitive policies in both the welfare and the criminal domains. It is not by accident that the advanced countries that have imported, first, workfare measures designed to buttress the discipline of desocialized wage work and, then, variants of U.S.-style criminal justice measures are the Commonwealth nations that also pursued aggressive policies of economic deregulation inspired by the "free-market" nostrums come from the United States, whereas the countries that remained committed to a strong regulatory state curbing social insecurity have best resisted the sirens of "zero tolerance" policing and "prison works." 16 Similarly, societies of the Second world, such as Brazil, Argentina, and South Africa, which adopted super-punitive penal planks inspired by U.S. developments in the 1990s and saw their prison populations soar as a result, did so not because they had at long last reached the stage of "late modernity," but because they have taken the route of market deregulation and state retrenchment. ${ }^{17}$ But to discern these multilevel connections between the upsurge of the punitive Leviathan and the spread of neoliberalism, it is necessary to develop a precise and broad conception of the latter. Instead of discarding neoliberalism, as Garland (2001:77) does, on account of it being "rather too specific" a phenomenon to account for penal escalation, we must expand our conception of it, and move from an economic to a fully sociological understanding of the phenomenon.

Neoliberalism is an elusive and contested notion, a hybrid term awkwardly suspended between the lay idiom of political debate and the technical terminology of social science, which moreover is often invoked without clear referent. Whether singular or polymorphous, evolutionary or revolutionary, the prevalent conception of neoliberalism is essentially economic: it stresses an array of market-friendly policies such as labor deregulation, capital mobility, privatization, a monetarist agenda of deflation and financial autonomy, trade

${ }^{16}$ In a major comparative study of the linkages between penal policy and political economy in 12 contemporary capitalist countries, Cavadino and Dignan (2006) find that the nations they characterize as neoliberal (as distinct from conservative corporatist, social democratic, and oriental corporatist) are consistently more punitive and have become much more so in the past two decades.

17 The international diffusion of "made in USA" penal categories and policies and its springs are treated at length in Prisons de Poverty (Wacquant, 2009b). For further analyses of this nearplanetary spread, read Jones and Newburn (2006) as well as Andreas and Nadelmann (2006). 
liberalization, interplace competition, and the reduction of taxation and public expenditures. ${ }^{18}$ But this conception is thin and incomplete, as well as too closely bound up with the sermonizing discourse of the advocates of neoliberalism. We need to reach beyond this economic nucleus and elaborate a thicker notion that identifies the institutional machinery and symbolic frames through which neoliberal tenets are being actualized.

A minimalist sociological characterization can now be essayed as follows. Neoliberalism is a transnational political project aiming to remake the nexus of market, state, and citizenship from above. This project is carried by a new global ruling class in the making, composed of the heads and senior executives of transnational firms, high-ranking politicians, state managers and top officials of multinational organizations (the OECD, WTO, IMF, World Bank, and the European Union), and cultural-technical experts in their employ (chief among them economists, lawyers, and communications professionals with germane training and mental categories in the different countries). It entails not simply the reassertion of the prerogatives of capital and the promotion of the marketplace, but the close articulation of four institutional logics.

1. Economic deregulation, that is, reregulation aimed at promoting "the market" or market-like mechanisms as the optimal device not only for guiding corporate strategies and economic transactions (under the aegis of the shareholder-value conception of the firm), but for organizing the gamut of human activities, including the private provision of core public goods, on putative grounds of efficiency (implying deliberate disregard for distributive issues of justice and equality).

2. Welfare state devolution, retraction, and recomposition designed to facilitate the expansion and support the intensification of commodification and, in particular, to submit reticent individuals to desocialized wage labor via variants of "workfare" establishing a quasi-contractual relationship between the state and lower-class recipients, treated not as citizens but as clients or subjects (stipulating their behavioral obligations as condition for continued public assistance).

3. An expansive, intrusive, and proactive penal apparatus that penetrates the nether regions of social and physical space to contain the disorders and disarray generated by diffusing social insecurity and deepening inequality, to unfurl disciplinary supervision over the precarious fractions of the postindustrial proletariat, and to reassert the authority of Leviathan so as to bolster the evaporating legitimacy of elected officials.

4. The cultural trope of individual responsibility, which invades all spheres of life to provide a "vocabulary of motive" - as C. Wright Mills would say-for the construction of the self (on the model of the

18 This is the common core one can extract from a vast (and uneven) literature on the topic across the disciplines, among which can be singled out the pointed analyses of Fligstein (2001) for sociology, Campbell and Pedersen (2001) for political economy, Comaroff and Comaroff (2001) for anthropology, Brenner and Theodore (2002) for geography, and Duménil and Lévy (2004) for economics. 
entrepreneur), the spread of markets and legitimization for the widened competition it subtends, the counterpart of which is the evasion of corporate liability and the proclamation of state irresponsibility (or sharply reduced accountability in matters social and economic).

A central ideological tenet of neoliberalism is that it entails the coming of "small government": the shrinking of the allegedly flaccid and overgrown Keynesian welfare state and its makeover into a lean and nimble workfare state, which "invests" in human capital and "activates" communal springs and individual appetites for work and civic participation through "partnerships" stressing self-reliance, commitment to paid work, and managerialism. Punishing the Poor demonstrates that that the neoliberal state turns out to be quite different in actuality: while it embraces laissez-faire at the top, releasing restraints on capital and expanding the life chances of the holders of economic and cultural capital, it is anything but laissez-faire at the bottom. Indeed, when it comes to handling the social turbulence generated by deregulation and to impressing the discipline of precarious labor, the new Leviathan reveals itself to be fiercely interventionist, bossy, and pricey. The soft touch of libertarian proclivities favoring the upper class gives way to the hard edge of authoritarian oversight, as it endeavors to direct, nay dictate, the behavior of the lower class. "Small government" in the economic register thus begets "big government" on the twofold front of workfare and criminal justice. Between 1982 and 2001, the United States increased its public expenditures for police, criminal courts, and corrections by $364 \%$ (from $\$ 36$ to $\$ 167$ billion, or $165 \%$ in constant dollars of 2000) and added nearly 1 million justice staff. In 1996, when "welfare reform" replaced the right to public aid by the obligation to accept insecure employment as a condition of support, the budget for corrections exceeded the overall sums allocated to AFDC and food stamps, the country's two main assistance programs. That same year, corrections vaulted to third largest employment in the land after Manpower Incorporated and Wal-Mart (see Wacquant, 2009a:152-161). The results of America's grand experiment in creating the first society of advanced insecurity in history are in: the invasive, expansive, and expensive penal state is not a deviation from neoliberalism but one of its constituent ingredients.

Remarkably, this is a side of neoliberalism that has been obfuscated or overlooked by its apologists and detractors alike. This blind spot is glaring in Anthony Giddens's celebrated reformulation of neoliberal imperatives into the platform of New Labour. In his manifesto for The Third Way, Giddens (1999) highlights high rates of crime in deteriorating working-class districts as an indicator of "civic decline" and curiously blames the Keynesian welfare state for it (not deindustrialization and social retrenchment): "The egalitarianism of the old left was noble in intent, but as its rightist critics say has sometimes led to perverse consequences - visible, for instance, in the social engineering that has left a legacy of decaying, crime-ridden housing estates." He makes "preventing crime, and reducing fear of crime" through state-locality partnerships central to 
"community regeneration," and he embraces the law-and-order mythology of "broken windows": "One of the most significant innovations in criminology in recent years has been the discovery [sic] that the decay of day-to-day civility relates directly to criminality. ... Disorderly behavior unchecked signals to citizens that the area is unsafe" (Giddens, 1999:16, 78-79, 87-88). But Giddens studiously omits the punishment side of the equation: The Third Way contains not a single mention of the prison and glosses over the judicial hardening and carceral boom that have everywhere accompanied the kind of economic deregulation and welfare devolution it promotes. This omission is particularly startling in the case of Britain, since the incarceration rate of England and Wales jumped from 88 inmates per 100,000 residents in 1992 to 150 per 100,000 in 2008, even as crime receded continually for the first 10 years of that period (Hough and Mayhew, 2004), with Anthony Blair presiding over the single largest absolute increase of the convict population during a prime ministership in the country's history-matching the feat of Clinton, his co-sponsor of the "Third Way" on the other side of the Atlantic.

A similar oversight of the centrality of the penal institution to the new government of social insecurity is found in the works of eminent critics of neoliberalism. David Harvey's (2005) extended characterization of "the neoliberal state" in his Brief History of Neoliberalism is a case in point, which appositely spotlights the obdurate limitations of the traditional political economy of punishment that Punishing the Poor strives to overcome. For Harvey, neoliberalism aims at maximizing the reach of market transactions via "deregulation, privatization, and withdrawal of the state from many areas of social provision." As in previous eras of capitalism, the task of Leviathan is "to facilitate conditions for profitable capital accumulation on the part of both domestic and foreign capital," but now this translates into penal expansion: "The neoliberal state will resort to coercive legislation and policing tactics (anti-picketing rules, for instance) to disperse or repress collective forms of opposition to corporate power .... The coercive arm of the state is augmented to protect corporate interests and, if necessary, to repress dissent. None of this seems consistent with neoliberal theory" (Harvey, 2005:2-3, 77, respectively. emphases supplied).

With barely a few passing mentions of the prison and not one line on workfare, Harvey's account of the rise of neoliberalism is woefully incomplete. His conception of the neoliberal state turns out to be surprisingly restricted, first, because he remains wedded to the repressive conception of power, instead of construing the manifold missions of penality through the expansive category of production. Subsuming penal institutions under the rubric of coercion leads him to ignore the expressive function and ramifying material effects of the law and its enforcement, which are to generate controlling images and public categories, to stoke collective emotions, and accentuate salient social boundaries, and well as to activate state bureaucracies so as to mold social ties and strategies. Next, Harvey portrays this repression as aimed at political opponents to corporate rule and "dissident internal movements" that 
challenge the hegemony of private property and profit (such as the Branch Davidians at Waco, the participants in the Rodney King riots in Los Angeles in 1991, and the antiglobalization activists who rocked the G-8 meeting in Seattle in 1999) (Harvey, 2005:83), when the primary targets of penalization in the post-Fordist age have been the precarious fractions of the proletariat concentrated in the tainted districts of dereliction of the dualizing metropolis who, being squeezed by the urgent press of day-to-day subsistence, have little capacity or care to contest corporate rule.

Third, for the author of Social Justice and the City the state "intervenes" through coercion only when the neoliberal order breaks down, to repair economic transactions, ward off challenges to capital, and resolve social crises. By contrast, Punishing the Poor argues that the present penal activism of the state - translating into carceral bulimia in the United States and policing frenzy throughout Western Europe - is an ongoing, routine feature of neoliberalism. Indeed, it is not economic failure but economic success that requires the aggressive deployment of the police, court, and prison in the nether sectors of social and physical space. The rapid turnings of the law-and-order merrygo-round are an index of the reassertion of state sovereignty, not a sign of its weakness. Harvey does note that the retrenchment of the welfare state "leaves larger and larger segments of the population exposed to impoverishment" and that "the social safety net is reduced to a bare minimum in favor of a system that emphasizes individual responsibility and the victim is all too often blamed" (Harvey, 2005:76), but he does not realize that it is precisely these normal disorders, inflicted by economic deregulation and welfare retrenchment, that are managed by the enlarged penal apparatus in conjunction with supervisory workfare. Instead, Harvey invokes the bogeyman of the "prison-industrial complex," suggesting that incarceration is a major plank of capitalist profit-seeking and accumulation when it is a disciplinary device entailing a gross drain on the public coffers and a tremendous drag on the economy.

Fourth and last, Harvey views the neoconservative stress on coercion and order restoration as a temporary fix for the chronic instability and functional failings of neoliberalism, whereas I construe authoritarian moralism as an integral constituent of the neoliberal state when it turns its sights on the lower rungs of the polarizing class structure. Like Garland, Harvey must artificially dichotomize "neoliberalism" and "neoconservatism" to account for the reassertion of the supervisory authority of the state over the poor because his narrow economistic definition of neoliberalism replicates its ideology and truncates its sociology. To elucidate the paternalist transformation of penality at century's turn, then, we must imperatively escape the "crime-and-punishment" box, but also exorcise once and for all the ghost of Louis Althusser (1971), whose instrumentalist conception of Leviathan and crude duality of ideological and repressive apparatuses gravely hamstring the historical anthropology of the state in the neoliberal age. Following Bourdieu, we must fully attend to the internal complexity and dynamic recomposition of the bureaucratic field, as well as to the constitutive power of the symbolic structures of penality to 
trace the intricate meshing of market and moral discipline across the economic, welfare, and criminal justice realms (Bourdieu, 1994:15-16; Wacquant, 2005:133-150).

\section{CONCLUSION: PENALITY IN THE BUILDING OF A CENTAUR STATE}

In his meticulous comparison of eugenic measures in the 1920s, compulsory work camps in the 1930s, and workfare schemes in the 1990s in the United Kingdom and the United States, Desmond King (1999:26) has shown that "illiberal social policies" that seek to direct citizens' conduct coercively are "intrinsic to liberal democratic politics" and reflective of their internal contradictions. Even as they contravene standards of equality and personal liberty, such programs are periodically pursued because they are ideally suited to highlighting and enforcing the boundaries of membership in times of turmoil; they are fleet vehicles for broadcasting the newfound resolve of state elites to tackle offensive conditions and assuage popular resentment toward derelict or deviant categories; and they diffuse conceptions of otherness that materialize the symbolic opposition anchoring the social order. With the advent of the neoliberal government of social insecurity mating restrictive workfare and expansive prisonfare, however, it is not just the policies of the state that are illiberal but its very architecture. Tracking the coming and workings of America's punitive politics of poverty after the dissolution of the Fordist-Keynesian order and the implosion of the black ghetto reveals that neoliberalism brings about not the shrinking of government, but the erection of a centaur state, liberal at the top and paternalistic at the bottom, which presents radically different faces at the two ends of the social hierarchy: a comely and caring visage toward the middle and upper classes, and a fearsome and frowning mug toward the lower class.

It bears stressing in closing that the building of a Janus-faced Leviathan practicing liberal paternalism has not proceeded according to some master scheme concocted by omniscient rulers. Nor does it spring mechanically from the systemic necessities of some grand structure such as late capitalism, racism, or panopticism (as in various neo-Marxist and neo-Foucauldian approaches, as well as in the activist demonology of the "prison-industrial complex"). Rather, it arises from struggles over and within the bureaucratic field, aiming to redefine the perimeter, missions, priorities, and modalities of action of public authorities with respect to definite problem territories and categories. These struggles involve, crucially, not only battles pitting organizations stemming from civil society and state agencies, but also internecine contests between the various sectors of the bureaucratic field, which vie to gain "ownership" of the social problem at hand and thus valorize the specific forms of authority and expertise they anchor (medical, educational, social welfare, penal, economic, etc., and within the penal domain, the police, courts, and confinement institutions and postcustodial means of control). The overall fitness of punitive 
containment to regulating urban marginality at century's dawn is a rough post hoc functionality born of a mix of initial policy intent, sequential bureaucratic adjustment, and political trial and error and electoral profit-seeking at the point of confluence of three relatively autonomous streams of public measures concerning the low-skill employment market, public aid, and criminal justice. The complementarity and interlocking of state programs in these three realms is partly designed and partly an emergent property, fostered by the practical need to handle correlated contingencies, their common framing through the lens of moral behaviorism and the shared ethnoracial bias stamping their routine operations - with (sub)proletarian blacks from the hyperghetto figuring at the point of maximum impact where market deregulation, welfare retrenchment, and penal penetration meet.

Whatever the modalities of their advent, it is indisputable that the linked stinginess of the welfare wing and munificence of the penal wing under the guidance of moralism have altered the makeup of the bureaucratic field in ways that are profoundly injurious to democratic ideals. ${ }^{19}$ As their sights converge on the same marginal populations and districts, deterrent workfare and the neutralizing prison foster vastly different profiles and experiences of citizenship across the class and ethnic spectrum. They not only contravene the fundamental principle of equality of treatment by the state and routinely abridge the individual freedoms of the dispossessed, they also undermine the consent of the governed through the aggressive deployment of involuntary programs stipulating personal responsibilities just as the state is withdrawing the institutional supports necessary to shoulder these and shirking its own social and economic charges. And they stamp the precarious fractions of the proletariat from which public aid recipients and convicts issue with the indelible seal of unworthiness. In short, the penalization of poverty splinters citizenship along class lines, saps civic trust at the bottom, and saws the degradation of republican tenets. The establishment of the new government of social insecurity discloses, in fine, that neoliberalism is constitutively corrosive of democracy.

By enabling us to break out of the crime-and-punishment box to relink welfare and justice while fully attending to both the material and symbolic dimensions of public policy, Bourdieu's concept of bureaucratic field offers a powerful tool for dissecting the anatomy and assembly of the neoliberal Leviathan. It suggests that some of the pivotal political struggles of this century's turn - if not the most visible or salient ones - involve not the confrontation between the mobilized organizations representing subaltern categories and the state, but battles internal to the hierarchical and dynamic ensemble of public bureaucracies that compete to socialize, medicalize, or penalize urban marginality and its correlates. Elucidating the nexus of workfare, prisonfare, and social insecurity, in turn, reveals that the study of incarceration is not a

19 For a specification of the republican and liberal conceptions of democracy at stake here, read David Held's (1996) Models of Democracy. 
technical section in the criminological catalogue but a key chapter in the sociology of the state and social inequality in the bloom of neoliberalism.

\section{REFERENCES}

Alesina, Alberto, and Edward L. Glaeser. 2004. Fighting Poverty in the US and Europe: A World of Difference. New York: Oxford University Press.

Althusser, Louis. 1971. "Ideology and Ideological State Apparatuses," in Lenin and Philosophy and Other Essays: pp. 127-186. New York/London: Monthly Review Press (Orig. pub. 1970).

Andreas, Peter, and Ethan Nadelmann. 2006. Policing the Globe: Criminalization and Crime Control in International Relations. New York: Oxford University Press.

Blumstein, Alfred, and Joel Wallman (eds.). 2000. The Crime Drop in America. New York: Oxford University Press.

Bonelli, Laurent. 2008. La France a peur. Une histoire sociale de l'insécurité. Paris: La Découverte.

Boullant, François. 2003. Michel Foucault et les prisons. Paris: Presses Universitaires de France.

Bourdieu, Pierre. 1994. "Rethinking the State: On the Genesis and Structure of the Bureaucratic Field," Sociological Theory 12(1): 1-19. (Orig. pub. 1993).

Bourdieu, Pierre. 1999. "The Abdication of the State," in Pierre Bourdieu et al., The Weight of the World: Social Suffering in Contemporary Society: pp. 181-188. Cambridge: Polity Press (Orig. pub. 1993).

Bourdieu, Pierre. 2005. The Social Structures of the Economy. Cambridge: Polity Press (Orig. pub. 2000).

Brenner, Neil, and Nik Theodore (eds.). 2002. Spaces of Neoliberalism: Urban Restructuring in North America and Western Europe. New York: Wiley/Blackwell.

Campbell, John, and Ove Pedersen (eds.). 2001. The Rise of Neoliberalism and Institutional Analysis. Princeton, NJ: Princeton University Press.

Cavadino, Michael, and James Dignan. 2006. Penal Systems: A Comparative Approach. London: Sage Publications.

Chih Lin, Ann. 1998. "The Troubled Success of Crime Policy," in Margaret Weir (ed.), The Social Divide: Political Parties and the Future of Activist Government: pp. 312-357. Washington, DC: Brookings Institution/Russell Sage Foundation.

Comaroff, Jean, and John L. Comaroff (eds.). 2001. Millennial Capitalism and the Culture of Neoliberalism. Durham, NC/London: Duke University Press.

Duménil, Gérard, and Dominique Lévy. 2004. Capital Resurgent: Roots of the Neoliberal Revolution. Cambridge: Harvard University Press.

Fligstein, Neil. 2001. The Architecture of Markets: An Economic Sociology of Twenty-First-Century Capitalist Societies. Princeton, NJ: Princeton University Press.

Foucault, Michel. 1977. Discipline and Punish: The Birth of the Prison. New York: Vintage (Orig. pub. 1975).

Freeman, Richard B. 2007. America Works: The Exceptional U.S. Labor Market. New York: Russell Sage Foundation.

Gallie, Duncan (ed.). 2007. Employment Regimes and the Quality of Work. Oxford: Oxford University Press.

Garland, David. 1989. Punishment and Society: A Study in Social Theory. Chicago: University of Chicago Press.

Garland, David. 2001. The Culture of Control: Crime and Social Order in Contemporary Society. Chicago: University of Chicago Press.

Garland, David. 2004. "Beyond the Culture of Control," Critical Review of International Social and Political Philosophy 7: 160-189.

Giddens, Anthony. 1999. The Third Way: The Renewal of Social Democracy. Cambridge: Polity Press.

Grandquillot, Dominique. 2009. RSA Revenu de solidarité active. Paris: Gualino Editeur.

Harvey, David. 2005. A Brief History of Neoliberalism. New York: Oxford University Press.

Hasenfeld, Yeheskel. 1972. "People Processing Organizations: An Exchange Approach," American Sociological Review 37(3): 256-263.

Held, David. 1996. Models of Democracy. Cambridge: Polity Press.

Hough, Mike, and Pat Mayhew. 2004. "L'évolution de la criminalité à travers deux décennies du British Crime Survey," Déviance et Société 28(3): 267-284. 
Jessop, Bob. 1994. "Post-Fordism and the State," in Ash Amin (ed.), Post-Fordism: A Reader: pp. 251-229. Oxford: Basil Blackwell.

Jones, Trevor, and Tim Newburn. 2006. Policy Transfer and Criminal Justice. Chichester: Open University Press.

Levy, Jonah D. (ed.). 2006. The State After Statism: New State Activities in the Age of Liberalization. Cambridge, MA: Harvard University Press.

Massey, Douglas S. 2007. Categorically Unequal: The American Stratification System. New York: Russell Sage Foundation.

Mathiesen, Thomas. 1990. Prison on Trial: A Critical Assessment. London: Sage Publications.

Maurin, Louis, and Patrick Savidan. 2008. L'Etat des inégalités en France. Données et analyses. Paris: Belin.

Musterd, Sako, Alan Murie, and Christian Kesteloot. 2006. Neighbourhoods of Poverty: Urban Social Exclusion and Integration in Comparison. London: Palgrave Macmillan.

Petersilia, Joan. 2008. "California's Correctional Paradox of Excess and Deprivation," Crime and Justice: A Review of Research 37: 207-278.

Piven, Frances Fox, and Richard A. Cloward. 1993. Regulating the Poor: The Functions of Public Welfare. New York: Vintage (Orig. pub. 1971).

Pratt, John. 2008a. "Scandinavian Exceptionalism in an Era of Penal Excess. Part I: The Nature and Roots of Scandinavian Exceptionalism," British Journal of Criminology 48: 119-137.

Pratt, John. 2008b. "Scandinavian Exceptionalism in an Era of Penal Excess. Part II: Does Scandinavian Exceptionalism Have a Future?" British Journal of Criminology 48: 275-292.

Schierup, Carl-Ulrik, Peo Hansen, and Stephen Castles. 2006. Migration, Citizenship and the European Welfare State: A European Dilemma. Oxford: Oxford University Press.

Shea, Evelyn. 2009. "Elections and the Fear of Crime: the Case of France and Italy," European Journal on Criminal Policy and Research 15: 1-2: 83-102.

Streeck, Wolfgang, and Kathleen Thelen (eds.). 2005. Beyond Continuity: Institutional Change in Advanced Political Economies. Oxford: Oxford University Press.

Tonry, Michael. 2004. Thinking About Crime: Sense and Sensibility in American Penal Culture. New York: Oxford University Press.

Wacquant, Loïc (ed.). 2005. The Mystery of Ministry: Pierre Bourdieu and Democratic Politics. Cambridge: Polity Press.

Wacquant, Loïc. 2008a. Urban Outcasts: A Comparative Sociology of Advanced Marginality. Cambridge: Polity Press.

Wacquant, Loïc. 2008b. "Ordering Insecurity: Social Polarization and the Punitive Upsurge," Radical Philosophy Review 11(1): 9-27.

Wacquant, Loïc. 2009a. Punishing the Poor: The Neoliberal Government of Social Insecurity. Durham/London: Duke University Press.

Wacquant, Loïc. 2009b. Prisons of Poverty. Minneapolis: University of Minnesota Press.

Wacquant, Loïc. 2010. Deadly Symbiosis: Race and the Rise of the Penal State. Cambridge: Polity Press, 2009.

Western, Bruce. 2006. Punishment and Inequality in America. New York: Russell Sage Foundation.

Wilson, William Julius. 1996. When Work Disappears: The World of the New Urban Poor. New York: Knopf.

Young, Iris Marion. 2005. "The Logic of Masculinist Protection: Reflections on the Current Security State," in Marilyn Friedman (ed.), Women and Citizenship: pp. 15-34. New York: Oxford University Press.

Young, Jock. 1999. The Exclusive Society: Social Exclusion, Crime and Difference in Late Modernity. London: Sage.

Zimring, Franklin, Gordon Hawkins, and Sam Kamin. 2001. Punishment and Democracy: Three Strikes and You're Out in California. New York: Oxford University Press. 